\title{
Rapid diagnosis of typhoid fever by co-agglutination in an Indian hospital
}

\author{
C. MUKHERJEE, ABIDA MALIK, H. M. KHAN and A. MALIK* \\ Department of Microbiology and *Paediatrics, J. N. Medical College, Aligarh 202002, UP, India
}

\begin{abstract}
Summary. Detection of Salmonella typhi infection by a co-agglutination assay for specific O, $\mathrm{H}$ and $\mathrm{Vi}$ antigens and by blood culture were compared for 110 patients with suspected typhoid fever. Blood cultures were positive for $S$. typhi in $25.5 \%$ of patients. Co-agglutination tests with patients' serum and with blood culture supernates gave positive results in $70.9 \%$ and $67.3 \%$ of cases respectively. S. typhi antigens $\mathrm{Hd}$ and $\mathrm{O} 9$ were detected in patients' serum by co-agglutination in $96.4 \%$ of blood culture-positive, and $62 \cdot 2 \%$ of blood culture-negative patients. Co-agglutination results were uniformly negative with serum samples from a control group of 50 healthy individuals, 20 patients with febrile non-typhoid infectious disease and 20 patients with non-infectious febrile disease. Of the 25 patients with suspected typhoid fever who had not received prior antibiotic treatment, $88 \%$ yielded positive blood cultures and $96 \%$ gave positive results in serum co-agglutination tests. By contrast, of the 85 patients who had received prior antibiotics, only $7 \%$ yielded positive blood cultures, but $63.5 \%$ gave positive results in serum co-agglutination tests. Co-agglutination tests with serum offer a simple, rapid, sensitive, specific and economical method for the early diagnosis of typhoid fever.
\end{abstract}

\section{Introduction}

Typhoid fever is rare in developed countries, ${ }^{1}$ but remains one of the most prevalent acute infectious diseases in the developing world. ${ }^{2}$ The disease presents a clinical dilemma because of its varied manifestations and serious complications. Early rapid detection and identification of the aetiological agent, Salmonella typhi, is essential in diagnosis and for treatment to reduce morbidity and mortality. Laboratory confirmation of the clinical diagnosis depends mainly upon blood culture, a time-consuming and costly technique. Serological diagnosis is of limited value ${ }^{3}$ and formal demonstration of a rising antibody titre invariably delays confirmation well beyond any reasonable time for initiation of therapy.

In this study, $S$. typhi-specific antigens were sought in co-agglutination tests with serum samples and blood-culture supernates and the results were compared with those of conventional blood culture.

\section{Materials and methods}

The study group comprised 110 patients diagnosed clinically as suffering from typhoid fever. Diagnosis was based on the presence of unremitting fever for
$>5$ days, systemic toxicity, fatigue, abdominal symptoms, transient rash and anorexia with a palpable spleen, especially in the second week of illness. A history was taken, including details of antibacterial therapy and duration of symptoms.

The control groups comprised: 50 healthy volunteers with no history of enteric fever or TAB vaccination in the previous year; 20 patients with other non-typhoid infectious disease; and 20 patients with febrile non-infectious disease (table I).

\section{Bacteriological and serological methods}

Routine blood culture with citrated glucose broth ${ }^{4}$ was done for all 110 patients with suspected typhoid fever. Blood $(5 \mathrm{ml})$ was collected aseptically by venepuncture and inoculated into $50 \mathrm{ml}$ of nutrient broth containing glucose $0.5 \%$ and sodium citrate $0.2 \%$. The blood cultures were incubated at $37^{\circ} \mathrm{C}$ for 14 days and inspected daily for growth.

Co-agglutination ${ }^{5}$ tests were performed on serum samples, and on blood culture supernates after incubation for $24 \mathrm{~h}$. One loopful of serum or blood culture supernate was placed on one half of a clean glass slide and another drop on the other half. A loopful of the appropriate co-agglutination reagent was placed on the first half, and another of normal rabbit serum (control) co-agglutination reagent was added to the other half. The pairs of drops were mixed 
Table I. Control groups

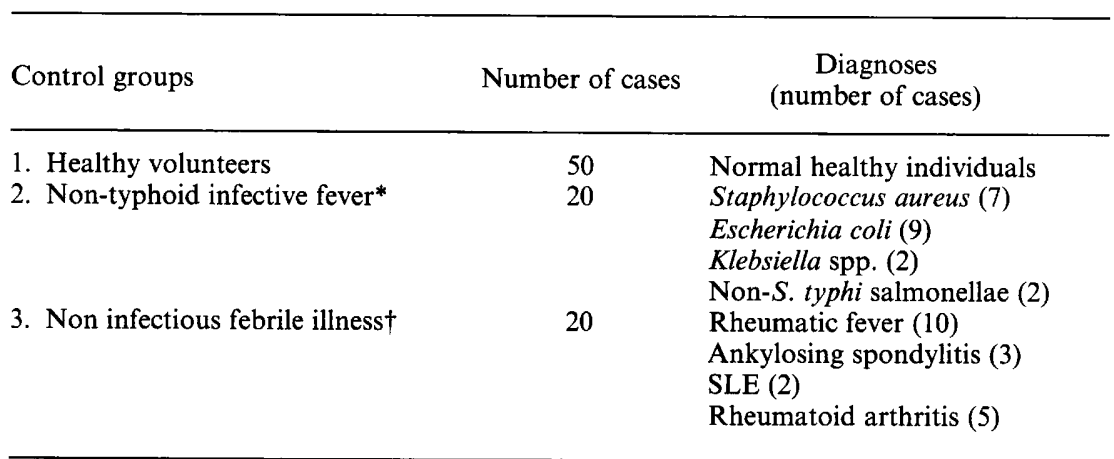

* Pathogens identified by standard procedure from blood culture.

$\dagger$ Diagnosed on the basis of clinical and laboratory findings.

Table II. Co-agglutination and blood culture positivity in relation to duration of fever on admission and prior antibacterial therapy

\begin{tabular}{|c|c|c|c|c|c|c|c|c|}
\hline \multirow{2}{*}{$\begin{array}{l}\text { Antibacterial therapy } \\
\text { before blood } \\
\text { culture }\end{array}$} & \multirow{2}{*}{$\begin{array}{l}\text { Duration } \\
\text { of } \\
\text { illness } \\
\text { (weeks) }\end{array}$} & \multirow{2}{*}{$\begin{array}{l}\text { Number of } \\
\text { patients }\end{array}$} & \multirow{2}{*}{$\begin{array}{l}\text { Total number }(\%) \\
\text { of patients }\end{array}$} & \multicolumn{2}{|c|}{$\begin{array}{l}\text { Number (\%) that were } \\
\text { blood-culture }\end{array}$} & \multicolumn{3}{|c|}{$\begin{array}{l}\text { Number }(\%) \text { that were } \\
\text { serum co-agglutination }\end{array}$} \\
\hline & & & & positive & negative & & ositive & negative \\
\hline No antibacterial therapy & $\begin{array}{l}1 \\
2 \\
3 \\
4\end{array}$ & $\left.\begin{array}{r}24 \\
1 \\
0 \\
0\end{array}\right\}$ & $25(22 \cdot 7)$ & $\left.\begin{array}{r}21 \\
1 \\
0 \\
0\end{array}\right\} 22(88)$ & $\left.\begin{array}{l}3 \\
0 \\
0 \\
0\end{array}\right\} 3(12)$ & $\left.\begin{array}{r}23 \\
1 \\
0 \\
0\end{array}\right\}$ & $\{24(96)$ & $\left.\begin{array}{l}1 \\
0 \\
0 \\
0\end{array}\right\} 1(4)$ \\
\hline Antibacterial therapy & $\begin{array}{l}1 \\
2 \\
3 \\
4\end{array}$ & $\left.\begin{array}{r}10 \\
60 \\
12 \\
3\end{array}\right\}$ & $85(77 \cdot 3)$ & $\left.\begin{array}{l}4 \\
2 \\
0 \\
0\end{array}\right\} 6(7 \cdot 1)$ & $\left.\begin{array}{r}6 \\
58 \\
12 \\
3\end{array}\right\} 79(92 \cdot 9)$ & $\left.\begin{array}{r}9 \\
44 \\
2 \\
-\end{array}\right\}$ & $\{54(63 \cdot 5)$ & $\left.\begin{array}{r}2 \\
16 \\
10 \\
3\end{array}\right\} 31(36 \cdot 5)$ \\
\hline Total & & & 110 & 28 & 82 & 78 & & 32 \\
\hline
\end{tabular}

and the slide was rotated by hand for $c .1-2$ min. Any visible clumping was noted. Agglutination with the $\mathrm{O} 9$ and $d$ reagents and no reaction with the normal rabbit serum reagent was interpreted as a positive test. Negative results were indicated by absence of reaction with the test and control reagents.

\section{Preparation of co-agglutination reagent}

A confluent growth of Staphylococcus aureus (Cowan 1) on Mueller-Hinton agar, incubated for $24 \mathrm{~h}$ at $37^{\circ} \mathrm{C}$, was emulsified in phosphate-buffered saline (PBS), pH 7.3, and washed five times with PBS containing formaldehyde $0.5 \%$. After incubation for $3 \mathrm{~h}$ at room temperature, the suspension was washed three times with PBS and heated at $80^{\circ} \mathrm{C}$ for $1 \mathrm{~h}$ with constant stirring. The heated suspension was washed three times with PBS, diluted 1 in 10 in PBS and stored overnight at $4^{\circ} \mathrm{C}$. One $\mathrm{ml}$ of the suspension was mixed with $0.1 \mathrm{ml}$ of antiserum. The antisera were: $\mathrm{O9}, \mathrm{Hd}$ and Vi salmonella antisera (National Salmonella and Escherichia Centre, Kasauli) and normal rabbit serum. After incubation for $3 \mathrm{~h}$ at room temperature, with gentle shaking at $30-\mathrm{min}$ intervals, these working reagents were stored at $4^{\circ} \mathrm{C}$.

\section{Results}

Blood cultures gave positive results for only 28 $(25.5 \%)$ of the 110 patients; $25(89.3 \%)$ of these 28 were tested in the first week of illness (table II). Of the 25 patients with no history of antibacterial therapy, 22 $(88 \%)$ gave blood cultures positive for $S$. typhi and 24 $(96 \%)$ gave positive serum co-agglutination results. Of the 85 patients who had received antibacterial agents, $54(63.5 \%)$ gave positive co-agglutination results and only $6(7 \cdot 1 \%)$ were blood-culture positive.

Serum co-agglutination tests gave positive results in $78(70.9 \%)$ of the patients. Of these, $85.3 \%$ were tested in the first week of illness, $77 \%$ in the second week, $16.7 \%$ in the third week and none in the fourth week. For the 28 blood culture-positive patients, serum coagglutination tests gave positive results in $27(96.4 \%)$ (table III). Of the 82 clinically diagnosed but bloodculture-negative patients, $51(62 \cdot 2 \%)$ gave positive results in serum co-agglutination tests.

Blood-culture supernates gave positive results in coagglutination tests for $74(67 \cdot 3 \%)$ patients. For the 28 blood culture-positive patients, $26(92.9 \%)$ gave positive co-agglutination results with 24 -h blood-culture supernates. Of 82 blood culture-negative patients, 48 
Table III. Detection of $S$. typhi by co-agglutination tests with blood culture supernates and serum

\begin{tabular}{|c|c|c|c|c|c|c|c|}
\hline \multirow{3}{*}{$\begin{array}{l}\text { Blood culture } \\
\text { result }\end{array}$} & \multirow{3}{*}{$\begin{array}{l}\text { Number of } \\
\text { patients }\end{array}$} & \multicolumn{6}{|c|}{$\begin{array}{l}\text { Number of patients that gave positive results } \\
\text { in co-agglutination tests with }\end{array}$} \\
\hline & & \multicolumn{3}{|c|}{ Blood culture supernate } & \multicolumn{3}{|c|}{ serum } \\
\hline & & O9 & d & $\mathrm{Vi}$ & O9 & d & $\mathrm{Vi}$ \\
\hline Positive & 28 & $\begin{array}{c}26 \\
(92 \cdot 9)\end{array}$ & $\begin{array}{c}26 \\
(92 \cdot 9)\end{array}$ & $\begin{array}{c}25 \\
(89 \cdot 3)\end{array}$ & $\begin{array}{c}27 \\
(96 \cdot 4)\end{array}$ & $\begin{array}{c}27 \\
(96 \cdot 4)\end{array}$ & $\begin{array}{c}26 \\
(92 \cdot 9)\end{array}$ \\
\hline Negative & 82 & $\begin{array}{c}48 \\
(58 \cdot 5)\end{array}$ & $\begin{array}{c}48 \\
(58 \cdot 5)\end{array}$ & $\begin{array}{c}48 \\
(58 \cdot 5)\end{array}$ & $\begin{array}{c}51 \\
(62 \cdot 2)\end{array}$ & $\begin{array}{c}51 \\
(62 \cdot 2)\end{array}$ & $\begin{array}{c}50 \\
(60 \cdot 9)\end{array}$ \\
\hline Total & 110 & $\begin{array}{c}74 \\
(67 \cdot 3)\end{array}$ & $\begin{array}{c}74 \\
(67 \cdot 3)\end{array}$ & $\begin{array}{c}73 \\
(66 \cdot 4)\end{array}$ & $\begin{array}{c}78 \\
(70 \cdot 9)\end{array}$ & $\begin{array}{c}78 \\
(70 \cdot 9)\end{array}$ & $\begin{array}{c}76 \\
(69 \cdot 1)\end{array}$ \\
\hline
\end{tabular}

Figures in parentheses indicate percentages.

$(58.5 \%)$ gave positive co-agglutination results with 24-h blood-culture supernates (table III).

Co-agglutination tests gave uniformly negative results with the 90 serum samples from the three control groups.

\section{Discussion}

Typhoid fever is a serious public health problem in India. Rapid laboratory diagnosis is essential for early therapy to reduce morbidity and mortality. However, isolation of $S$. typhi can be difficult, particularly when patients present late in the course of the disease, or after inadequate or inappropriate antibiotic therapy, as frequently happens in India.

In this study, the isolation rate of $S$. typhi from blood cultures was low; only $28(25.5 \%)$ of 110 clinically diagnosed patients (table II) were culturepositive. This low isolation rate may be due to prior antibacterial therapy or late presentation. The majority of patients in this study presented 2 weeks after onset of symptoms and after antibiotic therapy. Similar low isolation rates have been reported by various Indian authors. ${ }^{6,7}$

In contrast, serum co-agglutination tests gave positive results in $96.4 \%$ of the blood culture-positive patients and $62 \%$ of the blood culture-negative patients. John et al., ${ }^{8}$ in a study in Vellore, have also reported that serum co-agglutination tests gave positive results in $97 \%$ of blood culture-positive and $85 \%$ of blood culture-negative patients with clinically diagnosed typhoid fever.

Co-agglutination tests with blood-culture supernates in this study gave positive results with $67.3 \%$ of patients. Of the 28 blood culture-positive supernates, $92 \cdot 2 \%$ were co-agglutination-positive. Even among samples from 82 blood culture-negative patients, the co-agglutination test gave positive results in $58.5 \%$ of cases. Clearly, non-viable or antibiotic-suppressed organisms were present in many of these negative blood cultures.

Co-agglutination tests with serum showed maximum positivity for those patients in the first week of illness $(85.3 \%)$ reducing through the second and third weeks to $0 \%$ in the fourth week of illness.

The effects of prior antibacterial therapy on the results of serum co-agglutination tests and blood culture were significant. Of 25 cases that had not received antibacterial agents before sample collection, $24(96 \%)$ gave positive results in serum co-agglutination tests and $88 \%$ were blood culture-positive (table II). In patients who had already taken antibacterial agents, $63.5 \%$ were co-agglutination-positive whereas only $7 \cdot 1 \%$ gave positive results by conventional blood culture. Clearly the results of blood culture are more seriously affected than those of the co-agglutination test by the prior intake of antibacterial agents $\left(\chi^{2}=66 \cdot 76 ; \mathrm{p}=<0.001\right)$.

In the present study, co-agglutination has shown promise as a rapid, sensitive and specific method for the detection of $S$. typhi infection. The test is economical and the reagents maintained their activity for 3 months when kept at $4^{\circ} \mathrm{C}$.

\section{References}

1. Edelman R, Levine MM. Summary of an international workshop on typhoid fever. Rev Infect Dis 1986; 8: 329-349.

2. Cvjetanovic B, Grab B, Umera $K$. Typhoid fever; an endemic disease with interhuman transmission. Bull WHO 1978; 56 Suppl 1: 45-63.

3. Parker MT. Enteric infections: typhoid and paratyphoid fever. In: Wilson GS, Miles AA, Parker MT (eds) Topley and Wilson's Principles of bacteriology, virology and immunity, 7th edn, vol 3. London, Arnold Heinemann. 1984: 407-433.

4. Sleigh JD, Duguid JP. Salmonella. In: Collee JG, Duguid JP, Fraser AG, Marmion BP (eds) Mackie and McCartney's practical medical microbiology, 13th edn, vol 2. Edinburgh, Churchill Livingstone. 1989: 456-481.

5. Lesmana M, Dockhill RC, Sanbourn W. A coagglutination method for presumptive identification of $S$. typhi. Southeast Asian J Trop Med Public Health 1980; 11: 302-307. 
6. Dhanalakshmi D, Mallika M, Kumaravel, Bhavani M, Lakshminarayana CS. Detection of Salmonella typhi antigens by slide coagglutination in urine from patients with typhoid fever. Ind J Pathol Microbiol 1984; 27 : 33-36.

7. Bhat Kishore G, Metgud Sharada C, Patil CS. Rapid diagnosis of enteric fever by coagglutination. Ind $J$ Med Microbiol 1990; 8: 87-91.

8. John TJ, Sivadasan K, Kurien B. Evaluation of passive bacterial agglutination for the diagnosis of typhoid fever. $J$ Clin Microbiol 1984; 20: 751-753. 